\title{
A population based case-control study of agricultural injuries in children
}

\author{
DT Stueland, BC Lee, DL Nordstrom, PM Layde, LM Wittman
}

\begin{abstract}
Objectives-To identify preventable risk factors related to agricultural injuries occurring to children on family farms.

Setting-A geographically defined central region of Wisconsin, USA with nearly 1800 family dairy farms.

Methods-A two year, population based incidence study of occupational injuries among farm residents was conducted. For cases, trained staff abstracted information on the nature, severity, and treatment of the injury from the patient's medical record. Staff also administered a telephone questionnaire to cases and controls, usually answered by parents.
\end{abstract}

Results-There were 60 cases of farm residents younger than 18 years who sought care for acute agriculture related injuries. Farms on which uninjured children lived served as controls $(n=102)$. Multivariate analyses of 16 different variables revealed three significantly related to injuries to children: hours worked per week (odds ratio $(O R)=1 \cdot 05$; $95 \%$ confidence interval $(\mathrm{CI})=1.01$ to 1.08); presence of disabled safety device $(O R=2.64 ; 95 \% C I=1 \cdot 10$ to 6.35$)$; and feeding cows by grazing $(O R=0.22 ; 95 \%$ $\mathrm{CI}=\mathbf{0 . 0 6}$ to $8 \cdot 83$ ).

National Farm Medicine Center/Marshfield Medical Research Foundation and Marshfield Clinic, Marshfield, Wisconsin, USA

DT Stueland

BC Lee

Department of Epidemiology and Biostatistics,

Marshfield Medical

Research Foundation and Marshfield Clinic, Marshfield, Wisconsin, USA

DL Nordstrom

LM Wittman

Department of Family and Community Medicine, Medical College of Wisconsin, Milwaukee, Wisconsin, USA

PM Layde

Correspondence to: Dr Dean T Stueland, National Farm Medicine Center/Marshfield Medical Research Foundation, Research Foundation,
1000 North Oak Avenue 1000 North Oak Avenue, MSA.

Conclusions-Interventions designed to reduce the risk of agricultural injuries to farm children should acknowledge the participation of children as productive workers on the farm. Although education has been the standard method for encouraging safe practices in farm work, additional approaches, such as limiting the number of hours a child works, avoiding the disabling of safety devices, and using specific methods of managing cows, should also be adopted to minimize injury risks to farm children.

(Injury Prevention 1996; 2: 192-196)

Keywords: occupational, agriculture, case-control studies, rural health.

The past decade has witnessed considerable interest in the high incidence of fatal and non-fatal injuries associated with production agriculture. A unique aspect of this industry is that children of all ages frequently experience work related injuries by virtue of their participation of farm work as an unpaid family member or a paid employee. Additionally, some children experience injuries merely as bystanders to agricultural work. Sometimes it is difficult to distinguish whether a child was working, because children working on family farms would not necessarily be classified or described as employees.

Fatal and non-fatal childhood agricultural injury numbers and rates vary across the nation. In Wisconsin, four of the 40 farm related deaths in 1993 occurred to children younger than 15 years of age. ${ }^{1}$ In previous years $17.5 \%$ of the 1991 and $15.5 \%$ of the 1990 fatalities were children younger than 15 years. Children account for an even larger proportion of non-fatal injuries. In central Wisconsin over a two year period, $27 \%$ of 913 farm injury victims seeking emergency care were children. ${ }^{2}$ Rates of childhood farm injuries across the US are difficult to confirm, but range from $2 \cdot 3$ to 30.9 fatalities per 100000 rural residents among different age and sex cohorts of farm children. ${ }^{3}$ This variability is due to differences in characteristics selected for different studies, as well as a lack of a known denominator of children at risk.

While it is helpful to know the incidence and prevalence of childhood agricultural injuries, an understanding of etiologic factors is more important as a guide to prevention strategies. There have been few etiologic studies that have investigated precipitating factors and environmental conditions associated with children's exposure to agricultural hazards. In those studies published, certain agents, characteristics of hosts, and environmental factors such as social norms, have been described. A comprehensive review of the literature on childhood agricultural fatalities revealed that tractors were most involved and other machinery ranked second. ${ }^{4}$ In livestock enterprises, beef and dairy cows are associated with the higher incidence of non-fatal injuries. ${ }^{256}$ Characteristics of children injured as a result of agricultural hazards have been primarily described by age and sex. Several studies report peak rates in the preschool and early adolescent age groups. $^{247-9}$ In general, studies reveal a tendency for similar rates for boys and girls among preschoolers, with an increasing incidence among boys of school age.

Until recently, few farm injury reports differentiated the type of farming operation where an injury occurred. Several recent studies have contrasted the injury experience of dairy and non-dairy farms. ${ }^{561011}$ Although these studies focus primarily on adults, there is a suggestion of an increased risk of injury on dairy farms, probably associated with the great variety of tasks, proximity to large animals, and numerous types of machinery required to manage dairy livestock and conduct field work. 
According to the 1992 US Agriculture Census, $5.9 \%$ of the 1925300 farms in the US are categorized as dairy. ${ }^{12}$ These dairy farms accounted for $11.4 \%$ of the 64813 people experiencing a non-fatal injury and $12 \cdot 8 \%$ of the 642 farm sites on which a farm-related fatality occurred. Thus, it is possible that children are at greater risk for agriculture related trauma when living on, or visiting, dairy farms compared with other types of farms.

Looking beyond the US, several countries report childhood fatality cases associated with agriculture, and some offer findings from surveillance of non-fatal injuries. Several Canadian provinces provide annual fatality reports with case descriptions of childhood agricultural fatality victims. ${ }^{1314}$ Nearly all the Canadian fatalities are associated with tractors, trucks, or all terrain vehicles. A recent analysis of 283 farm machinery injuries among children in Ontario, Canada estimated injury rates of 116 per 100000 boys and a ratio of boy to girl injury rates of $4 \cdot 5: 1 .{ }^{15}$ Surveillance of injuries to farmers and farm workers in New Zealand revealed that children accounted for $34 \%$ of the fatalities on farms. ${ }^{16}$ These were typically drownings or tractor related events. In England and Wales, children represent nearly $25 \%$ of farm fatalities, ${ }^{17}$ which are associated with tractors, machinery, and falling objects. The University Institute of Forensic Medicine in Copenhagen reported on 33 fatalities associated with agriculture of which $21 \%$ were victims younger than 20 years. ${ }^{18}$ Again, fatalities were associated with tractors, machinery, and falls. Sweden's official data report the total number of childhood injury fatalities, without specific reference to agriculture related events but estimate there are three to five childhood fatalities annually associated with agriculture. ${ }^{19}$ Twenty one per cent of farm injury victims in four midland hospitals of Ireland were children. ${ }^{20}$ Serious injuries to children in Irish farms centered around tractors and machinery as well as falls from heights. The consistency of injury events noted here may be related to similarities in the role children have served on family farms as they exist across many geographic regions. This consistency also implies that selected childhood agricultural injury prevention strategies may be applicable internationally.

This study was conducted to determine whether specific characteristics of individuals or farm operations were associated with agriculture related injuries to children. The focus was primarily on factors associated with methods of agricultural production that would lend themselves to manipulation or elimination, and ultimately, injury prevention.

\section{Methods}

This investigation was based on agricultural injuries occurring during a 24 month period from May 1990 through April 1992 in the Marshfield Epidemiologic Study Area (MESA). MESA, a geographically defined area comprising 12 ZIP (postal) codes in central Wisconsin, is a largely rural area with a single small city and surrounding villages. ${ }^{21}$ Family owned dairy farms account for the majority of the approximately 1800 agricultural enterprises in this area. A single medical center is essentially the sole medical care provider. Virtually all primary, secondary, and tertiary care of area residents is provided by Marshfield Clinic and Saint Joseph's Hospital. This study is restricted to children under the age of 18 living on farms in the area. Details of case surveillance and determination of the control population have been previously described. ${ }^{10}$ Cases were defined as farm resident children who sought medical or chiropractic care for acute agriculture related injuries between May 1990 and April 1992. Children were eligible to become cases each time they were injured. There was no restriction on mechanism of injury, providing it was unintentional and related to the performance, observation, or proximity to farm work. Strict criteria were established and monitored to ensure all cases reflected acute agriculture related events to children residing on farms in the catchment area.

Possible control farmers were identified from four lists: (1) participants in the US Agricultural Stabilization and Conservation Service Federal Farm Subsidy Program; (2) dairy milk producers registered with the Wisconsin Department of Agriculture, Trade, and Consumer Protection; (3) individuals holding reduced rate farm motor vehicle licenses from the Wisconsin Department of Transportation; and (4) subscribers to AgriView, a weekly farm newspaper from the area. Individuals from these lists were contacted by telephone to confirm that their residence was a farm. Residents were then linked with other members of their household, using computerized data at Marshfield Clinic. A simple random sample of farm households with children was selected as control farms. Because the unit sampled for cases was individuals, while for controls it was farms, another study design variable was the number of children residing on the farm.

Trained staff abstracted information regarding the nature, severity, and treatment of the injury from the patient's medical records. Interviewers administered a telephone questionnaire to cases and controls to obtain information on selected demographic characteristics, general safety behaviors, farming practices, and farm characteristics. If children were younger than 12 years of age, interviewers requested information from a parent. The interview response rate for case children (or their parent) was $93.8 \%$. The response rate for controls of all ages was $82 \cdot 8 \%$. Rates of occupational injuries to children were presented as person years of risk. No attempt was made to adjust hours worked, because some of the children were merely observing work.

Several potential risk factors for farm injuries were evaluated. The association of each factor with case-control status was assessed, adjusting for sex and number of residents on the farm. All factors associated with casecontrol status by a $p$ value of $<0.25$ were 
evaluated in a multivariate logistic regression model. Variables were entered in the model in the order of increasing probability for their association with case-control status in the univariate analysis.

\section{Results}

A total of 64 farm injuries were identified in children residing in MESA. Sixty ( $94 \%$ ) of the children (or families) were interviewed and served as cases for the study (table 1). Comparing children older than 13 years with those 13 and younger, only one $(0.07 \%)$ of the 15 of the older group was observing rather than participating in work $\left(\chi^{2}=17 \cdot 3299 ; p=0.0002\right)$. There was a trend for injury rates to increase with age for males and decrease for females. The highest injury rate was experienced by males age $14-17$ years $(27 \cdot 2$ injuries per 1000 farm resident persons by age and sex). Of the 15 injury cases among children younger than 7 years of age, $11(73.3 \%)$ were not involved in work. Of the 30 injury cases among children age $7-13$, seven $(23.3 \%)$ of the cases were not involved with work.

Data collected on numerous characteristics of the farm to case-control status revealed 14 univariate analyses characteristics with a probability of $<0 \cdot 25$. These variables, as well as sex and number of children living on the farm, were subjected to subsequent analyses. The characterization of each of these variables is depicted in table 2 .

Multivariate estimates of farm characteristics to case-control status are shown in table 3. For every hour worked, the rate of injury increased by nearly $5 \%$. Disabling a safety device significantly increases the risk of injury (odds ratio $(O R)=2 \cdot 64$ ), whereas feeding cows by grazing is associated with lower risk of injury $(O R=0 \cdot 22)$.

The 60 children in this study suffered injuries to various parts of the body, most often the upper extremity, as noted in table 4. For three children, the primary injury was ingestion. The most common diagnoses were contusions and lacerations, followed by factures (table 5).

\section{Discussion}

This study documents the rate and significant risk factors associated with non-fatal agriculture related injuries requiring medical attention to children in central Wisconsin. Certain

Table 1 Age, sex, number, and rate ${ }^{\star}$ of childhood agricultural injuries

\begin{tabular}{|c|c|c|c|c|c|c|c|c|c|c|c|c|}
\hline \multirow[b]{2}{*}{ Age (years) } & \multicolumn{4}{|l|}{ Males } & \multicolumn{4}{|c|}{ Females } & \multicolumn{4}{|l|}{ Total } \\
\hline & $\begin{array}{l}\text { Total } \\
\text { at risk }\end{array}$ & $\begin{array}{l}\text { No } \\
\text { injured } \dagger\end{array}$ & Rate & $95 \% C I$ & $\begin{array}{l}\text { Total } \\
\text { at risk }\end{array}$ & $\begin{array}{l}\text { No } \\
\text { injured } \dagger\end{array}$ & Rate & $95 \% C I$ & $\begin{array}{l}\text { Total } \\
\text { at risk }\end{array}$ & $\begin{array}{l}\text { No } \\
\text { injured } \dagger\end{array}$ & Rate & $95^{\circ}{ }_{o} C I$ \\
\hline $\begin{array}{l}0-6 \\
7-13 \\
14-17\end{array}$ & $\begin{array}{l}246 \\
385 \\
221\end{array}$ & $\begin{array}{r}8(5) \\
20(5) \\
12(1)\end{array}$ & $\begin{array}{l}16 \cdot 26 \\
25 \cdot 97 \\
27 \cdot 15\end{array}$ & $\begin{array}{l}4.99 \text { to } 27.53 \\
14.57 \text { to } 37.36 \\
11.79 \text { to } 42.51\end{array}$ & $\begin{array}{l}228 \\
346 \\
216\end{array}$ & $\begin{array}{r}7(6) \\
10(2) \\
3(0)\end{array}$ & $\begin{array}{r}15 \cdot 35 \\
14.45 \\
6.94\end{array}$ & $\begin{array}{l}3.98 \text { to } 26.72 \\
5.49 \text { to } 23.41 \\
0.00 \text { to } 14.80\end{array}$ & $\begin{array}{l}474 \\
731 \\
437\end{array}$ & $\begin{array}{l}15(11) \\
30(7) \\
15(1)\end{array}$ & $\begin{array}{l}15 \cdot 82 \\
20 \cdot 52 \\
17 \cdot 16\end{array}$ & $\begin{array}{l}7 \cdot 82 \text { to } 23 \cdot 83 \\
13 \cdot 18 \text { to } 27 \cdot 86 \\
8 \cdot 48 \text { to } 25 \cdot 85\end{array}$ \\
\hline Total & 852 & $40(11)$ & $23 \cdot 47$ & 16.20 to 30.75 & 790 & $20(8)$ & 12.66 & $7 \cdot 11$ to $18 \cdot 21$ & 1642 & $60(19)$ & $18 \cdot 27$ & 13.65 to 22.89 \\
\hline
\end{tabular}

$\star$ Rate of farm injuries in children per 1000 farm resident persons by age and sex.

$\dagger$ Number in parentheses represents number of children injured while playing or bystanding, rather than working. $\mathrm{CI}=$ confidence interval.

Table 2 Characteristics of farms where a child suffered an injury compared with control farms

\begin{tabular}{|c|c|c|c|c|c|c|}
\hline Variable & $p^{\star}$ & Status & No $(\%)$ cases & No $(\%)$ controls & $O R$ & $95 \% C I$ \\
\hline Hours worked/week/hour & $<0.01$ & $\begin{array}{l}\text { Non } \\
\text { Continuous }\end{array}$ & $\begin{array}{l}12(22 \cdot 6) \\
41(77 \cdot 4)\end{array}$ & $\begin{array}{l}42(41 \cdot 2) \\
60(58 \cdot 5)\end{array}$ & $\begin{array}{l}1.00 \\
1.04\end{array}$ & $\begin{array}{l}\text { Referent } \\
1.02 \text { to } 1.07\end{array}$ \\
\hline Allowed riders on tractor & 0.02 & No & $12(21 \cdot 8)$ & $42(41 \cdot 6)$ & 1.00 & $\begin{array}{l}1.02 \text { to } 1.07 \\
\text { Referent }\end{array}$ \\
\hline & & Yes & $43(78 \cdot 2)$ & $59(58 \cdot 4)$ & 2.56 & $1 \cdot 14$ to $5 \cdot 76$ \\
\hline Any cows registered & 0.03 & No & $41(77 \cdot 4)$ & $50(61 \cdot 0)$ & 1.00 & Referent \\
\hline & & Yes & $12(22 \cdot 6)$ & $32(39.0)$ & $0 \cdot 40$ & 0.17 to 0.92 \\
\hline Grade of milk & 0.03 & $\begin{array}{l}\text { Grade A } \\
\text { Grade B } \\
\text { None/other }\end{array}$ & $\begin{array}{r}38(63 \cdot 3) \\
15(25 \cdot 0) \\
7(11 \cdot 7)\end{array}$ & $\begin{array}{l}61(59 \cdot 8) \\
13(12 \cdot 8) \\
28(27 \cdot 5)\end{array}$ & $\begin{array}{l}1.00 \\
1.93 \\
0.40\end{array}$ & $\begin{array}{l}\text { Referent } \\
0.76 \text { to } 4.90 \\
0.14 \text { to } 1.15\end{array}$ \\
\hline Milks cows fed by grazing & 0.04 & No & $17(32 \cdot 1)$ & $41(51.9)$ & 1.00 & Referent \\
\hline Farm income & 0.05 & $\begin{array}{l}\text { Yes } \\
\$ 0-1000 \\
\$ 1001-10000 \\
\$ 10001+\end{array}$ & $\begin{array}{c}36(67 \cdot 9) \\
1(1.9) \\
11(20 \cdot 4) \\
42(77 \cdot 8)\end{array}$ & $\begin{array}{c}38(48 \cdot 1) \\
9(9 \cdot 1) \\
12(12 \cdot 1) \\
78(78 \cdot 8)\end{array}$ & $\begin{array}{r}2 \cdot 23 \\
1 \cdot 00 \\
11 \cdot 77 \\
5 \cdot 30\end{array}$ & $\begin{array}{l}1.04 \text { to } 4.89 \\
\text { Referent } \\
1.03 \text { to } 134.60 \\
0.54 \text { to } 51.75\end{array}$ \\
\hline Dairy is a primary product & 0.08 & $\begin{array}{l}\text { No } \\
\text { Yes }\end{array}$ & $\begin{array}{r}6(10.2) \\
53(89.8)\end{array}$ & $\begin{array}{l}26(25 \cdot 7) \\
75(74 \cdot 3)\end{array}$ & $\begin{array}{l}1.00 \\
2.53\end{array}$ & $\begin{array}{l}\text { Referent } \\
0.88 \text { to } 7 \cdot 25\end{array}$ \\
\hline Tractor drivers under age 16 & $0 \cdot 15$ & $\begin{array}{l}\text { No } \\
\text { Yes }\end{array}$ & $\begin{array}{l}23(42 \cdot 6) \\
31(57 \cdot 4)\end{array}$ & $\begin{array}{l}58(61 \cdot 1) \\
37(39.0)\end{array}$ & $\begin{array}{l}1.00 \\
1.71\end{array}$ & $\begin{array}{l}\text { Referent } \\
0.82 \text { to } 3.57\end{array}$ \\
\hline No of persons working/not living on farm & $0 \cdot 16$ & $\begin{array}{l}0 \\
1 \text { or more }\end{array}$ & $\begin{array}{l}37(63 \cdot 8) \\
21(36 \cdot 2)\end{array}$ & $\begin{array}{l}79(79 \cdot 8) \\
20(20 \cdot 2)\end{array}$ & $\begin{array}{l}1.00 \\
1.75\end{array}$ & $\begin{array}{l}\text { Referent } \\
0.81 \text { to } 3.80\end{array}$ \\
\hline Disabled safety device for farm machinery & $0 \cdot 17$ & $\begin{array}{l}\text { No } \\
\text { Yes }\end{array}$ & $\begin{array}{r}51(87.9) \\
7(12.1)\end{array}$ & $\begin{array}{l}78(78.0) \\
22(22.0)\end{array}$ & $\begin{array}{l}1.00 \\
0.51\end{array}$ & $\begin{array}{l}\text { Referent } \\
0.19 \text { to } 1.34\end{array}$ \\
\hline No of tillable acres & $0 \cdot 20$ & $\begin{array}{l}<75 \\
75-149 \\
150-199 \\
200-299 \\
300+\end{array}$ & $\begin{array}{r}6(10 \cdot 7) \\
18(32 \cdot 1) \\
9(16 \cdot 1) \\
7(12 \cdot 5) \\
16(28 \cdot 6)\end{array}$ & $\begin{array}{l}22(21 \cdot 8) \\
27(26 \cdot 2) \\
18(17 \cdot 8) \\
23(22 \cdot 8) \\
11(10 \cdot 9)\end{array}$ & $\begin{array}{l}1.00 \\
2.21 \\
1.44 \\
1.00 \\
3.23\end{array}$ & $\begin{array}{l}\text { Referent } \\
0.73 \text { to } 6.71 \\
0.41 \text { to } 5.12 \\
0.28 \text { to } 3.50 \\
0.92 \text { to } 11.34\end{array}$ \\
\hline Manure handling/liquid & $0 \cdot 21$ & No & $40(71 \cdot 4)$ & $68(70 \cdot 8)$ & 1.00 & Referent \\
\hline & & $\begin{array}{l}\text { Yes } \\
\text { No }\end{array}$ & $\begin{array}{l}16(28.6) \\
47(85.5)\end{array}$ & $28(29 \cdot 2)$ & 0.58 & 0.25 to 1.35 \\
\hline Made safety device for farm machinery & $0 \cdot 11$ & $\begin{array}{l}\text { No } \\
\text { Yes }\end{array}$ & $\begin{aligned} 47(85 \cdot 5) \\
8(14 \cdot 6)\end{aligned}$ & $\begin{array}{l}83(84 \cdot 7) \\
15(15 \cdot 3)\end{array}$ & $\begin{array}{l}1.00 \\
0.39\end{array}$ & $\begin{array}{l}\text { Referent } \\
0.12 \text { to } 1.25\end{array}$ \\
\hline Milking cows fed from bunk wagon & $0 \cdot 24$ & $\begin{array}{l}\text { No } \\
\text { Yes }\end{array}$ & $\begin{array}{l}17(32 \cdot 1) \\
36(67 \cdot 9)\end{array}$ & $\begin{array}{l}19(24 \cdot 1) \\
60(76 \cdot 0)\end{array}$ & $\begin{array}{l}1.00 \\
0.61\end{array}$ & $\begin{array}{l}\text { Referent } \\
0.27 \text { to } 1.39\end{array}$ \\
\hline
\end{tabular}

${ }^{\star} \mathrm{p}$ Value from univariate analyses of those variables with $\mathrm{p}=<0 \cdot 25$. Missing data were excluded. CI $=$ confidence interval. 
Table 3 Multivariate relationships for variables related to farm injuries in children

\begin{tabular}{lll}
\hline Variable & $O R$ & $95^{\circ}{ }_{o} C I$ \\
\hline Hours worked/week/hour & 1.05 & 1.01 to 1.08 \\
Disabled safety device & 2.64 & 1.10 to 6.35 \\
Milk cows fed by grazing & 0.22 & 0.06 to 0.83 \\
\hline
\end{tabular}

$\mathrm{CI}=$ confidence interval.

Table 4 Body part affected by agricultural injuries of children in central Wisconsin

\begin{tabular}{ll}
\hline Anatomical area & No $\left({ }^{\circ}{ }_{o}\right)^{\star}$ \\
\hline Upper extremity & $26(43 \cdot 3)$ \\
Lower extremity & $16(26 \cdot 7)$ \\
Head & $10(16 \cdot 7)$ \\
Face & $9(15 \cdot 0)$ \\
Eye & $3(5 \cdot 0)$ \\
Alimentary canal & $3(5 \cdot 0)$ \\
Back & $2(3 \cdot 3)$ \\
Chest & $1(1 \cdot 7)$ \\
\hline
\end{tabular}

^Per cent of total who suffered an injury to that anatomical area.

Table 5 Diagnoses for children suffering agricultural injuries in central Wisconsin

\begin{tabular}{lc}
\hline Category & No $\left(\%_{o}^{\star}\right)^{\star}$ \\
\hline Contusion or abrasion & $19(31 \cdot 7)$ \\
Laceration & $17(28 \cdot 3)$ \\
Fracture & $10(16 \cdot 7)$ \\
Puncture & $5(8.3)$ \\
Burn & $4(6 \cdot 7)$ \\
Closed head injury & $4(6 \cdot 7)$ \\
Sprain & $3(5 \cdot 0)$ \\
Evulsion & $2(3 \cdot 3)$ \\
Poisoning & $2(3 \cdot 3)$ \\
Foreign body & $1(1 \cdot 7)$ \\
Other & $1(1 \cdot 7)$ \\
\hline
\end{tabular}

*Per cent of the total with each diagnosis. Some children received more than one diagnosis.

limitations of this study should be considered Within the study area, dairy farming on family enterprises is the predominant form of agriculture. Therefore, we could not identify if the risk factors for injuries apply to other agricultural settings, including non-dairy farms or large, corporate farms. The interviews covered a number of potential farm related risk factors, but did not explore any individual factor in depth. Pre-existing conditions of children were not explored. Finally, the small number of cases limits statistical power.

Nearly one third $(31.7 \%)$ of the 60 children were observing others at work at the time of injury. A key injury prevention strategy is maintaining sufficient distance between a child and the work that is occurring. The blending of work and play areas for children on farms has been a major concern for agricultural safety specialists. As recommended by others, construction of barriers between play and work sites may include fences or other guarded areas in the farm setting..$^{15}$ Ideally, children should not be present near any hazardous work site.

Results of the study indicated there was nearly a 5\% increase in injury risk for every hour that was worked by a child younger than 18 years of age. This observation is important in that it parallels findings of adult studies suggesting that hours of exposure are an important risk factor. ${ }^{5}$ However, a complicating factor is that there are no relevant guidelines upon which parents or employees can determine a 'safe' number of hours for a young person to be involved in agricultural work. Federal and state employment standards for children's involvement in farm work stipulate guidelines regarding number of hours of work before and after school, weekend, and during the summer, but generally do not apply to family farms.

Another issue to be considered regarding the increased number of hours of work is the absence of national or general guidelines regarding developmentally or age appropriate tasks for children. Given the exemption of family farms from safety standards established by the Occupational Safety and Health Administration (OSHA), ${ }^{22}$ the parent or employer is dependent on social norms or his/her intuition to determine whether a child has the physical and cognitive skills to engage in specific tasks. Parents' assessment of a child's readiness to engage in farm work is generally assumed to be adequate and protective for the child. However, studies regarding risk perception of parents indicate that they have difficulty judging differences between high and low risk activities and often perceive their own child as being able to handle high risk situations more competently than other children. ${ }^{2324}$

The absence of safety devices on agricultural machinery as a preventable risk factor is a significant finding when contrasting child injuries with adult injuries. While farmers have lobbied to be excluded from OSHA standards on family farms, this independence has been perceived as a privilege or right of adult workers as they determine an acceptable level of risk for themselves. ${ }^{25}$ This issue becomes troubling, however, when children are voluntarily, or unknowingly, exposed to known hazards such as unguarded power take-off shafts or other moving machinery.

The third preventable risk factor identified in this study, grazing versus other types of feeding dairy cows, is of interest because of the growing tendency of young farmers to adopt rotational grazing as the preferred method of feeding livestock. Although there are many possible motivations for doing so, this study suggests that this practice may reduce the risk of injury to children.

\section{Implications for preventions}

As long as production agriculture involves families, children will continue to be exposed to agricultural hazards, either as participants or bystanders to the work. This study suggests that farm owner/operators, parents, and adolescent workers should set reasonable standards for total number of hours worked, appropriate tasks (based on physical and cognitive skills of the child), and the requirement that no children are present in work sites where safety devices are disabled. These injury prevention strategies may be applicable to any farm setting where children are exposed to hazards, such as livestock and machinery.

This research was supported by the US Centers for Disease Control and Prevention, grant no R49CCR-503652. 
1 Purschwitz MA, Skjolaas C. Wisconsin 1993 farm-related fatalities. Madison, WI: University of Wisconsin Extensatalities. 1994.

2 Stueland D, Layde PM, Lee BC. Agricultural injuries in children in central Wisconsin. F Trauma 1991; 31: 1503-9.

3 Stallones L, Gunderson P. Epidemiological perspectives on childhood agricultural injuries within the United States. fournal of Agromedicine 1994; 1: 3-18

4 Purschwitz MA. Fatal farm injuries to children. Report for the Office of Rural Health Policy. Wisconsin Rural Health Research Center. Marshfield, WI: Marshfield Clinic, 1990.

5 Gerberich S, Gibson R, Gunderson P, et al. Regional rural injury study (RRIS): a population based effort. In: McDuffie HH, Dosman JA, Semchuk KM, Olenchock SA, Senthilselvan A, eds. Supplement to agricultural A place, environment, sustainability Saskatoon, Saskatchewan: Centre for Agricultural Medicine, University of Saskatchewan, 1994: 195-200.

6 Pratt DS, Marvel LH, Darrow D, Stallones L, May JJ, Jenkins P. The dangers of dairy farming: the injury experience of 600 workers followed for 2 years. Am $\mathcal{F}$ Ind Med 1992; 21: 637-50.

7 Cogbill TH, Busch HM Jr, Stiers GR. Farm accidents in children. Pediatrics 1985; 76: 562-6.

8 Tormoehlen R. Fatal farm accident occurring to Wisconsin children, 1970-1984. ASAE paper No 86-5514. Chicago, IL: American Society of Agricultural Engineers, 1986.

9 Swanson JA, Sachs MI, Dahlgren KA, Tinguely SJ. Accidental farm injuries in children. Am $\mathcal{F}$ Dis Child 1987; 141: $1276-9$.

10 Nordstrom DL, Layde PM, Olson KA, Stueland DT, Brand $\mathrm{L}$, Follen MA. The incidence of farmwork-related acute injury in a defined population. Am $\mathcal{F}$ Ind Med 1995; 28: $551-64$.

11 Zhou C, Roseman JM. Agricultural injuries among a population-based sample of farm operators in Alabama. population-based sample of farm ope
12 United States Department of Commerce. 1992 Census of agriculture: geographic area series. Vol 1, part 51 . agriculture: geographic area series. Vol 1, part 51.

Washington, DC: US Government Printing Office, 1994.
13 Farm Safety Association Inc. Fatality report. Farmsafe 1995; 20: 8-9.

14 Dick L, ed. Reaping the benefits. Safety on the farm. Injury Prevention News 1995; 8: 1-23.

15 Pickett W, Brison RJ, Hoey JR. Fatal and hospitalized agricultural machinery injuries to children in Ontario, Canada. Injury Prevention 1995; 1: 97-102.

6 Clarke JA, Marshall SW, Langley JD, Cryer C Epidemiology of injuries occurring on New Zealand farms: $a$ report to the Accident Rehabiliation and Compensation Insurance Corporation. Dunedin: University of Otago, New Zealand, 1995.

17 Cameron D, Bishop C, Sibert JR. Farm accidents in children. BMF 1992; 305: 23-5.

18 Albrektsen SB, Henriksen BM, Thomsen JL. Fatal agricultural accidents. Med Sci Law 1993; 33: 340-4

19 The Children's Ombudsman. Up to 18 facts about children and adolescents. Statistics. Stockholm: Sweden 1995 [in Swedish].

20 Doyle Y. Farming and industrial accidents in the midlands during 1981 - a pilot study. Ir Med $\Im$ 1984; 77: 277-83.

21 Nordstrom DL, Remington PL, Layde PM. The utility of HMO data for the surveillance of chronic diseases. $A m^{\mathcal{F}}$ Public Health 1994; 84: 995-7.

22 United States Department of Labor. Child labor requirements in agriculture under the Fair Labor Standards Act. (Child labor bulletin No 102.) Washington, DC: US Government Printing Office, 1990.

23 Gärling T, Gärling A. Adults' assessments of children's accident risks. Psychol Rep 1987; 60: 1003-10.

24 Mickalide AD. Parents' perceptions and practices concerning childhood injury: 1987 versus 1992 . Childhood Injury Prevention Quarterly 1993; 4: 29-32.

25 Kelsey TW. The agrarian myth and policy responses to farm safety. Am $\mathcal{F}$ Public Health 1994; 84: 1171-7.

\section{Facts with a twist}

An interesting, and potentially attention grabbing way of experiencing injury statistics, is the following:

3437, motor vehicle collision: one death every three hours.

2138, accidental fall: one death every four hours.

1050, suicide by firearm: one death every eight hours.

210, homicide: cutting/piercing instrument: one death every 42 hours.

154, surgical/medical misadventure: one death every two days.

63, fatal gun accidents: one death every six days.

(Causes of Death 1992, Statistics Canada, September 1994).

\section{Canadian trends}

According to Statistics Canada, over the last 20 years the death rate due to injuries has decreased by at least $50 \%$ for children under 14 years of age and by $33 \%$ for youths 15 to 19 years of age. But the rates of hospitalization due to injury for children and youths remain strikingly high, despite a drop across all age groups since 1980. In 1989-90, over 15550 hospital admissions among preschoolers were due to injuries: 15786 among 5 to 9 year olds, 18116 among 10 to 14 year olds, and 28470 among teenagers 15 to 19 years of age. 